\title{
Interactive comment on "Biogeography and community structure of abyssal scavenging Amphipoda (Crustacea) in the Pacific Ocean" by Tasnim Patel et al.
}

\section{Tasnim Patel et al.}

tpatel@naturalsciences.be

Received and published: 19 October 2018

The comment was uploaded in the form of a supplement:

https://www.biogeosciences-discuss.net/bg-2018-347/bg-2018-347-AC1-

supplement.pdf 